Omni-Akuatika, 14 (2) :66-72,2018
ISSN: 1858-3873 print / 2476-9347 online
Research Article
journal homepage: http://ojs.omniaquatika.net

\title{
Characteristics of Gel Emulsion Formulation of Snakehead (Channa Micropeltes) As Wound Healer
}

\author{
Firlianty $^{1^{*}}$, Choirul Anwar ${ }^{1}$, Elita ${ }^{1}$, Anang Najamuddin ${ }^{2}$, Silvester B. Pratasik $^{3}$ \\ ${ }^{1}$ Study Program of Fisheries Product Technology, Dept. Fisheries, Faculty of Agriculture, Palangka Raya \\ University, Indonesia \\ ${ }^{2}$ Faculty of Agriculture, Palangka Raya University, Indonesia \\ ${ }^{3}$ Faculty of Fisheries and Marine Science, Sam Ratulangi University Manado, Jl. Kampus Bahu, Manado-95115, \\ Sulawesi Utara, Indonesia
}

*Corresponding author: firlianty80@gmail.com

\begin{abstract}
This study is aimed to know the characteristics and the effectivity of gel emulsion of snakehead (Channa micropeltes) extract in accelerating wound healing process. It used experimental method with Complete Randomized Design. Four treatments with 3 replications were employed, i.e. $1 \%, 2 \%$, and $4 \%$ gel emulsion of snakehead Channa micropeltes extract and a control treatment. Results showed that $C$. micropeltes extract formulated in gel emulsion had white colour, typical aroma of gel emulsion, soft texture with mean dispersion ability of $3 \mathrm{~cm}$, and $\mathrm{pH} 6$. In vivo test on male mices that gel emulsion of $C$. micropeltes extract was highly effective $(P \leq 0.05)$ to accelerate wound healing, in which the treatment of $1 \%$ gel emulsion gave the highest effect with $98.5 \%$ wound healing at day-14, followed with that of control treatment, $95 \%$ healing, then $2 \%, 90 \%$ healing and $4 \%, 90 \%$ healing, respectively. Snakehead (Channa micrpeltes) extract formulated in gel emulsion can speed up the wound healing process.
\end{abstract}

Keywords : Gel emulsion, snakehead (Channa micropeltes), wound healing.

\section{Introduction}

Wounds are damages of body tissues often followed with loss of tissue substance that disturbs normal cellular process of the body, particularly skin (Sinambela et al 2013; Daisa et al 2017). Wound healing is a natural process of the body in regeneration of damaged skin tissue by supplying tissue perfusion, sufficient oxygen, and appropriate nutrition. One of the principles in wound healing is to provide enough nutrients since nutrient intake is specifically highly needed to increase the wound strength, to decrease dehydration, and to reduce the vulnerability to infection. Nutrient intake, such as carbohydrate, protein, fat, and micronutrients, is very important in increasing the body defense mechanisms to help wound healing process (Widjianingsih \& Wirjatmadi, 2013).

Toman snakehead (Channa micropeltes) is one of the freshwater fishes that have body weight up to twice the other snakehead species and holds albumin protein. Albumin is protein type beneficial for new tissue formation of the body at the growth age and useful for nutrient supply in wound healing (Hairima et al 2014; Nicodemus et al 2014). Firlianty et al (2013) found that albumin content in C. micropeltes is high enough compared with that in other snakeheads, such as $C$. striata, $C$. pleuropthalma, and $C$. lucius. Beside that, $C$. micropeltes possesses high tape density of albumin protein and the most complete amino acids (Firlianty 2016). The use of albumin from C. micropeltes as wound healer has been practiced many times by consuming the fish as food or directly consuming the extract liquid. However, albumin of $C$. Micropeltes has fishy smell, and some people do not like it. Gel emulsion production is an alternative solution in wound healing drug development.

Gel emulsion, as one of good topical medicines in drug transport system, gel and emulsion releasing systems, in which the emulsion that could carry hydrophobic liquid extract of $C$. micropeltes is proportional to gel that possesses local effect to reduce pain at the inflammatory phase (Mutmainnah, 2015). Besides, gel emulsion is capable of efficiently bringing the active compound of $C$. micropeltes albumin to the skin evenly and maintaining it in 
the skin tissues and cells and gives

This study was conducted to prove that gel emulsion characteristics of $C$. micropeltes extract and its effectivity on wound healing.

\section{Material and Methods}

This study was experimental using gel emulsion of snakehead (Channa micropeltes) extract to cure the white rat (Mus musculus) cut the dorsal part as long as $2 \mathrm{~cm}$ and about 2 $\mathrm{mm}$ deep. This therapy was done on 4 groups of the white rats at 0 (control), $1 \%, 2 \%$, and $4 \%$ of gel emulsion of the extract.

\section{Emulsion Processing}

Extract of C. micropeltes was dissolved in $0.5 \%$ span $80,7.5 \%$ liquid paraffin up to forming liquid phase, and at the same time oil phase was accomplished by dissolving $1 \%$ tween 80 in distilled water up to forming oil phase. After oil phase and liquid phase had been gained, the oil phase was mixed into the liquid phase through heating up to reaching $70^{\circ} \mathrm{C}$ and stirred at $300 \mathrm{rpm}$ for $15 \mathrm{~min}$. up to emulsion formed.

\section{Gel Production}

Gel was made by dissolving carbopol 934 and trietanolamine in distilled water and stirred at $400 \mathrm{rpm}$ up to homogenous and gel basis formed. pharmacological effects (Vikas, 2012).

\section{Gel Emulsion Production}

Gel emulsion was made by adding with sediaan emulsi of $C$. micropeltes extract into the gel basis and stirred at $400 \mathrm{rpm}$ for $20 \mathrm{~min}$. up to gel emulsion of $C$. micropeltes extract formed

\section{Characteristic test and in vivo test}

The characteristic examination of gel emulsion covered $\mathrm{pH}$, dispersing ability, and organoleptic. In vivo test was done on male mice, Mus musculus, with weight range of $20-$ $40 \mathrm{~g}$ that had been acclimated for 7 days and then treated with gel emulsion of $C$. micropelte twice a day for 14 days at a dose of $0.5 \mathrm{~g}$. Wound healing development was observed at day-1, day-7, and day-14, respectively. Change in wound length was calculated using the following formula:

$$
=\frac{\begin{array}{l}
\text { Change in wound in length }(\%) \\
\text { Initial wound length-Wound length at day }-\mathrm{n}
\end{array}}{\text { Initial wound length }} \times 100
$$

\section{Statistical Analysis}

The experiment applied Complete Randomized Design with 4 treatments and 3 replications. ANOVA was used to see the effect on $\mathrm{pH}$, dispersion, and change in wound length.

\section{Result and Discussion}

\section{Emulsion gel characteristics}

The characteristics of gel emulsion and dispersion of C. micropeltes extract are presented in Figure 1, and the organoleptic in Table 1.

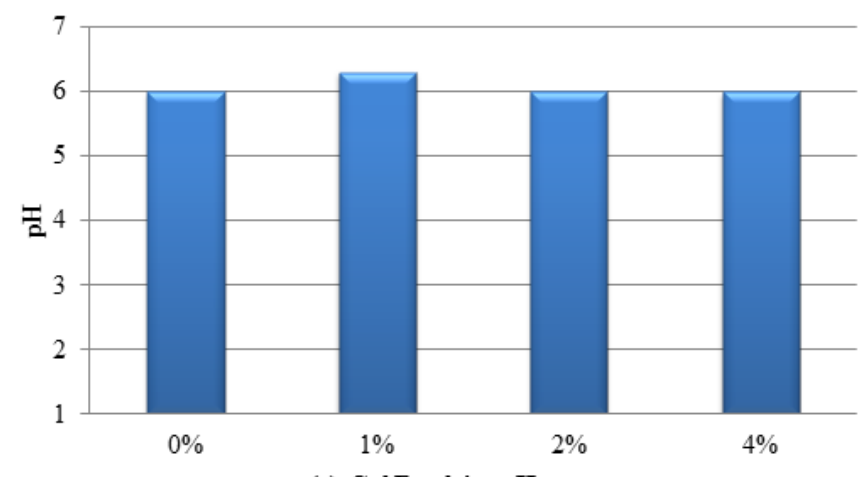

(a). Gel Emulsion pH 


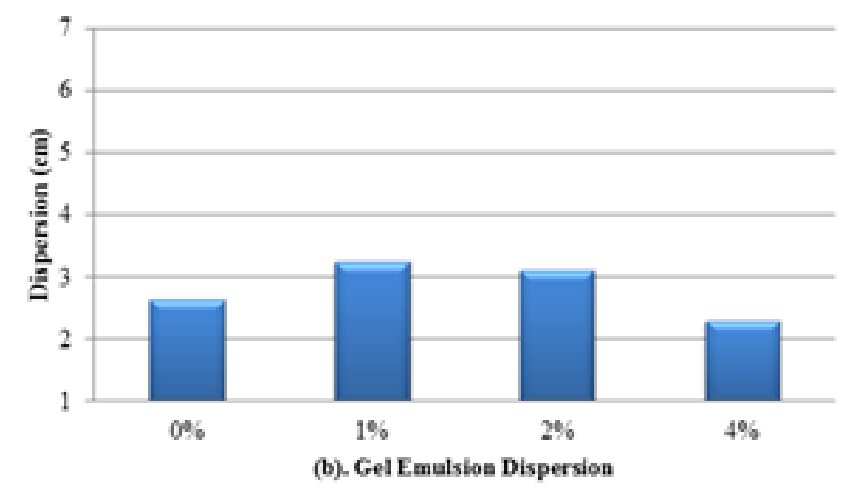

Figure 1. (a) Gel emulsion $\mathrm{pH}$ and, (b) Gel emulsion dispersion

Table 1. Organoleptic of gel emulsion of $C$. micropeltes

\begin{tabular}{cccc}
\hline Formula & Color & Aroma & Texture \\
\hline $0 \%$ & white & Typical smell & Soft \\
$1 \%$ & white & Typical smell & Soft \\
$2 \%$ & white & Typical smell & Soft \\
$4 \%$ & White & Typical smell & Soft
\end{tabular}

Measurements of $\mathrm{pH}$ are part of the gel emulsion examination (Figure 1a). ANOVA indicated that addition of $C$. micropeltes extract did not significantly affect the gel emulsion $\mathrm{pH}$ $(P \geq 0.05)$. Our findings are in the range suggested by Rowe et al., 2009, $4.5-6.4$, so that the gel emulsion it is safe to use and does not cause skin irritation.

Dispersion ability is important in emulsion formulation to ease the application on the skin (Garg et al, 2002). ANOVA showed that addition of $C$. micropeltes extract significantly influenced the scatter of gel emulsion $(P \leq 0.05)$ in which treatment of $1 \%$ extract gave the highest dispersion with mean of $3.25 \mathrm{~cm}$. Addition of $1 \%, 2 \%$, and $4 \%$ of $C$. micropeltes extract to the gel emulsion could be well dispersed in the gel emulsion. $C$. micropeltes extract also contains albumin with flexible structure (due to change in disulfide) and the shape easily changes with environmental condition variations (Fitriayi \& Deviarni, 2013).

For organoleptic test (Table 1), the addition of $C$. micropeltes extract to the gel emulsion did not give difference in organoleptic features, such as color, odor, and texture. The emulsion had white color, typical odor, soft texture, and no clumps of small particles

\section{In vivo test}

Percent wound healing development mice (Mus musculus), is presented in Figure 2. 


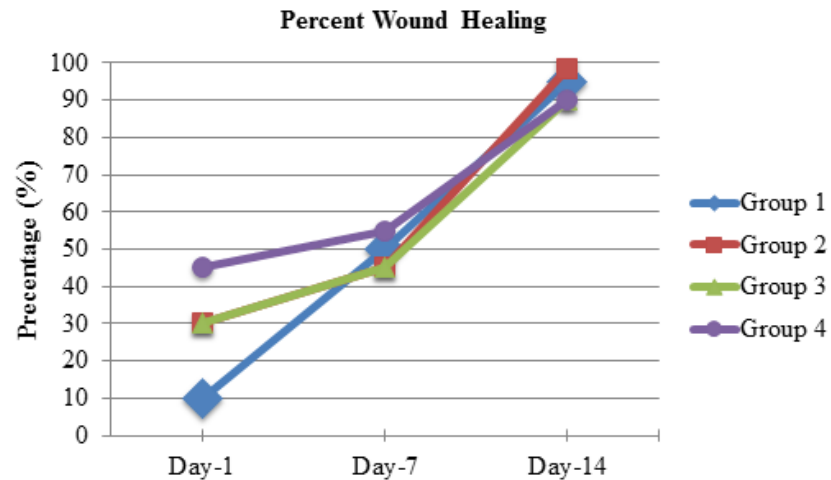

Figure 2. Percent wound healing
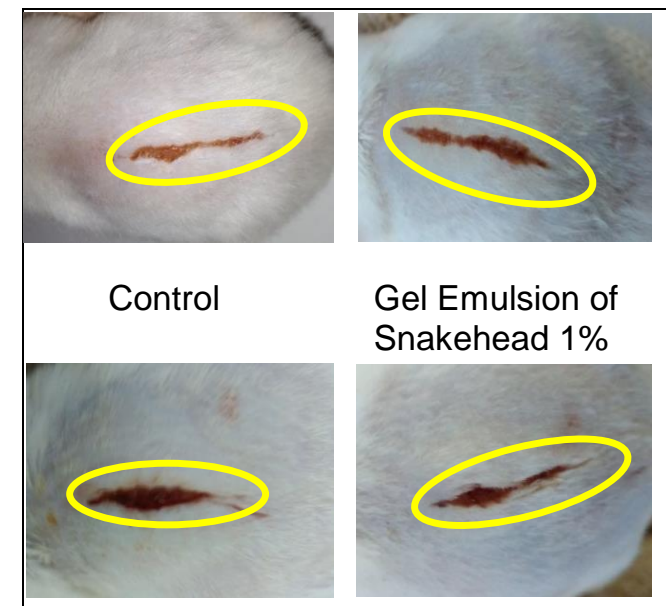

Gel Emulsion of Snakehead $1 \%$

Gel Emulsion of

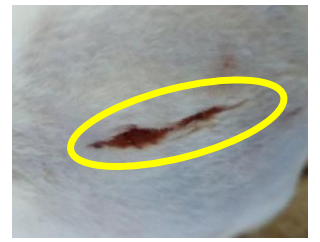

Snakehead 2\%

Gel Emulsion of Snakehead $4 \%$

Figure 3. Wound conditions of negative control and gel emulsion of $C$. micropeltes at day-1

ANOVA showed significant difference among experimental groups ( $\mathrm{P} \leq 0.05)$, in which treatment of $1 \%$ extract gave the highest healing effect with mean $98.5 \%$ of healing at day-14. Each experimental group, in general, reflects wound healing as given in Figure 2.

Wound healing process at day-1 naturally occurs as an early stage of wound healing called inflammatory phase. This phase starts from wound constriction due to skin inflammation caused by foreign materials from outside the body that enter through the open wounds, trigger a disturbance of hydrostatic pressure and cause different concentrations inside and outside the cell through the osmotic path (Alauddin, 2015). Figure 3 demonstrates natural wound healing. These conditions require albumin that can maintain the osmotic pressure inside and outside the cell, so that the healing process of the wound can continue. 


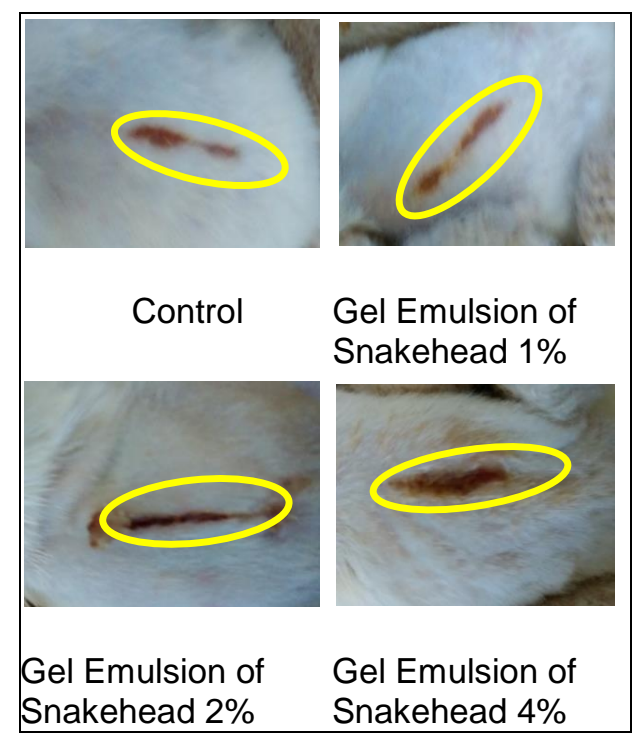

Figure 4. Wound Conditions of Negative Control and Gel Emulsion of Snakehead at day-7

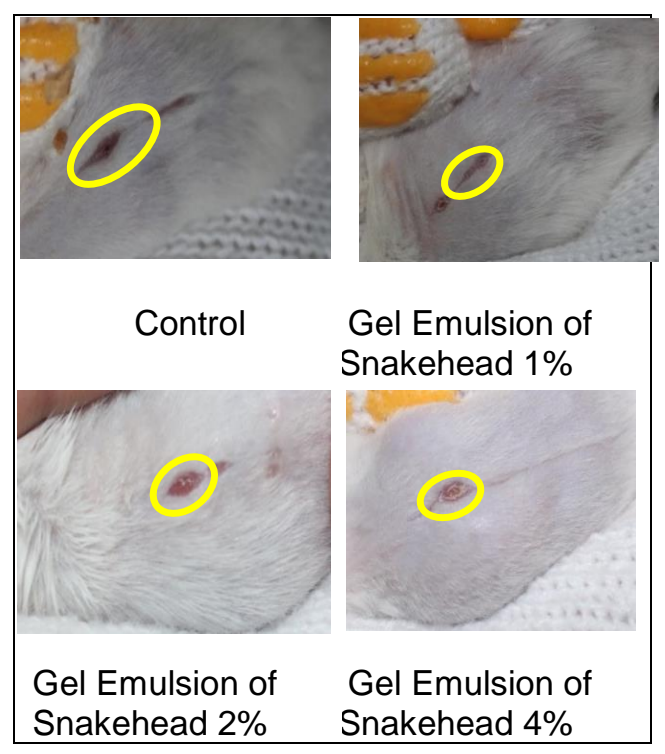

Figure 5. Wound conditions of negative control and gel emulsion of C. micropeltes at day-14

At day-7, albumin absorption of gel emulsion of $C$. micropeltes extract on the wound occurred called proliferation phase. In this phase, albumin plays important role in closing the wound area. Figure 4 shows the wound healing in proliferation phase. Irwanda et al. (2014) added that during proliferation, albumin plays important role to influence the level and quality of wound healing, collagen formation, and collagen strength. Futhermore, amino acids and fatty acids, play important roles in the synthesis of collagen fibers during the wound healing process (Mustafa et al 2012., Wahab et al 2012., Tamales et al 2016).
At day-14, collagen reorganization occurred to form cell tissues and increased the collagen strength of the skin called maturation phase.

Figure 5 demonstrates wound covering process. In this phase, albumin in the gel emulsion has important role in collagen formation. Wahab et al (2015) said that these two compounds were believed to be involved in the promotion of wound healing by the initiation of a series of mechanisms involving the remodelling of collagen, and reepithelialisation of the wound. 


\section{Conclusion}

Addition of snakehead's $C$. micropelte extract formulated into gel emulsion had white color, typical smell of gel emulsion, soft texture with mean dispersion of $3 \mathrm{~cm}, \mathrm{pH}=6$. In vivo test on male mice (Mus musculus), Gel emulsion of snakehead (C. micropeltes) can speed up the wound healing process.

\section{References}

Alauddin, Ariq. 2015. The effect of snakehead (Channa striata) extract orally administered on cut wound of male wistar rat. Jurnal Mahasiswa Farmasi Fakultas Kedokteran UNTAN. 3 (1): 112. [in Indonesian]

Daisa, Fransisca., Andrie, Mohamad., \& Taurina, Wintari. 2017. The Effectiveness Test of Oil Phase Ointment Containing Snakehead Fish (Channa striata) Extract on Open Stage II Acute Wounded Wistar Strain Male Rats. Traditional Medicine Journal. 22 (7): 97102.

Firlianty., Suprayitno, Eddy., Nursyam, Happy., Hardoko., \& Mustafa, Annasari. 2013. Chemical Composition and Amino Acid Profile of Channidae Collected From Central Kalimantan, Indonesia. International Journal of Science and Technology (IJSTE). 2 (4): 25-29.

Fitriyani, Evi., \& Deviarni, M.I. 2013. The use of snakehead (Channa Striata) extract albumin as basic material of wound healing cream. Jurnal Vokasi. 9 (3): 166174.

Garg, Alka., Anggarwal, Deeplka., \& Singla, Anil K. 2002. Spreading of Semisolid Formulation. www.Pharmtech.com: 8890.

Hairima., Andrie, Mohammad., \& Fahrurroji, Andhi. 2014. Activity test of liquid phase wound drug of snakehead (Channa micropeltes) extract on white wistar rat. Jurnal Mahasiswa Farmasi Fakultas Kedokteran dan IImu Kesehatan UNTAN 1 (1): 1-14. [in Indonesian]

Irwanda, Welly F., Andrie, Mohammad., \& Luliana, Sri. 2015. Test on the healing effect of liquid-phase toman snakehead (Channa micropeltes) extract on the cut wound of white wistar rat. Jurnal
Mahasiswa Farmasi Fakultas

Kedokteran dan IImu Kesehatan UNTAN 3 (1): 1-14. [in Indonesian].

Laverius, Manda F. 2011. Tween 80 and Span 80 optimization as emulsifying agent and Carbopol as gelling agent in emulgel photoprotector preparation of green tea (Camellia sinensis L.) extract: Aplikasi Desain Faktorial. Fakultas Sanata Dharma. Yogyakarta: 1-71. [in Indonesian]

Mustafa, Annasari., Widodo, M. A., \& Kristianto, Yohanes. 2012. Albumin and Zinc Content of Snakehead Fish (Channa striata) Extract and Its Role in Health. IEESE International Journal of Science and Technology (IJSTE) 1 (2): 1-8.

Mutmainnah. 2015. Formulation and characteristic test of emulger of snakehead (Channa striatus) extract. Universitas Islam Negeri Alauddin. Makassar: 1-64. [in Indonesian]

Nicodemus., Andrie, Mohammad., \& Luliana, Sri. 2014. Test on healing effect of oral administration of snakehead (Channa micropeltes) extract on cut wound healing of male wistar rat. Jurnal Mahasiswa Farmasi Fakultas Kedokteran dan IImu Kesehatan UNTAN 1 (1): 1-14. [in Indonesian]

Rowe, Raymond C., Sheskey, Paul J., \& Quinn, Marian E. 2009. Handbook of Phamaceutical Expients : Sixth Edition. Pharmaceutical Press and American Pharmacist Association : USA \& UK. 110.

Sinambela, Herry Yovieta., Pratiwi, Liza., \& Sari, Rafika. 2013. Formulation optimization of cream preparation of snakehead (Channa striata Bloch) oil as cut wound drug using Simplex Lattice Design method. Lembaga Penelitian Universitas Tanjungpura:10-1. [in Indonesian].

Tamales, Devintha AM., Dewi, Nurdiana, \& Rosida, Lena. 2016. Extract of haruan (channa striata) extract increasing reepithelialization count in wound healing process on wistar rat's buccal mucosa. Journal of Dentomaxillofacial Science $(\mathrm{J}$ Dentomaxillofac Sci ) 1 (1): 12-15.

Vikas, Singla. 2012. Emulgel: A New Platform For Topical Drug Delivery: International 
Journal of Pharma and Bio Sciences:h. 485-498.

Wahab, Siti Z., Kadir, Azidah., Hussain, Nik., Omar, Julia., Yunus, Rohaizan., Baie, Saringat., Noor, Norhayati., Hasan, Intan., Mahmood, Wan., Razak, Aranee., \& Yusoff, Wan. 2015. The Effect of Channa striatus (Haruan) Extract on Pain and Wound Healing of Post-Lower Segment Caesarean Section Women. Hindawi Publishing Corporation Evidence-Based Complementary and Alternative Medicine.

http://www.hindawi.com: 1-6.

Widjianingsih, Elok., \& Wirjatmadi, Bambang. 2013. Hubungan Tingkat Konsumen Gizi dengan Proses Penyembuhan Luka Pascaoperasi Section Cesarea. Jurnal Media Gizi Indonesia 9 (1): 1-5. [in Indonesian] 